<症例報告 $>$

還元型グルタチオンが著効を奏した切除不能肝細胞癌の 1 例

河野 信博 長尾 桓 瀬戸山隆平 森岡 恭彦*

要 旨：本症例は59歳の女性で, 肝腫大を主訴として来院した. AFP 高值 $(113,574.5 \mathrm{ng} / \mathrm{m} l)$, 画像診断, 細胞診等より, 肝両葉にわたり肝体積の $50 \%$ 以上を占めるびをん型肝細胞癌と診断 され，局所進展高度のため切除不能と判定された. Noviにより肝細胞癌に対する有効性が示唆 された還元型グルタチオンの大量投与 $(5 \mathrm{~g} /$ 日) 開始し, 肝機能検査, AFP, 超音波検查, CT にて経過を追跡した。投与開始 3 カ月後には，全身状態の改善, AFP 值の低下 $(360 \mathrm{ng} / \mathrm{m} l)$ と ともに, 画像診断上肝腫煬の質的変化, 縮小が観察された。 6 力月後には AFP の再上昇傾向が みられたので, 還元型グルタチオンを $5 \mathrm{~g} /$ 日から $10 \mathrm{~g} /$ 日に增量した. その結果 AFP の再上昇は 㧕制され，畽煌は順調に縮小傾向を続けた。投与開始後 1 年 6 力月を経過した現在，畽晹の体 積は肝全体の $5 \%$ 以下にまで消退し，患者は社会的に活躍中である.

索引用語： 肝細胞癌 還元型グルタチオン

はじめに

肝細胞癌の有効な治療法には, 切除療法, 血行遮断 療法, 薬物療法等があるが，長期生存，治燱が期待で きるのは切除療法のみである”。しかし，われわれが日 常遭遇する肝細胞癌の多くは進行癌で発見されること が多く，切除不能の場合が多い。近年, 腫湯マーカー, 画像診断法の開発導入が図られ，早期に発見される肝 細胞癌症例は增加しつつあるが，この場合む高率に併 存する肝硬変症のため肝予備力が低下しており，切除 断念せざるを得ないことが多い，因みに日本肝癌研 究会の第 5 回全国集計'では全肝癌症例のわずか $26.6 \%$ 切除が可能であったにすぎない，この数字は 非治癁切除をむ含むので, 治瘾切除例に限ればこの率 は更に減少する。換言すれば肝癌の多くは血行遮断， 化学療法などの姑息的治療法に頼らさるを得ないのが 現状である。

1981年, Novi は還元型グルタチオン（以下 GSH と 略す. Fig. 1) が Aflatoxin $B_{1}$ によるットの実験肝 癌を消退せしめることを報告しだ2。これは完成され た癌を化学薬剤の投与のみにより消退せしめた世界で 最初の研究である。わ机わはこの事実注目し，切 除不能肝癌に対する「GSH 大量療法」を 2 年前より実 地臨床の場で開始し，有效例を得つつあるが，本稿で はそのらち著効を呈した 1 症例を報告する。

\section{* 東京大学医学部第 1 外科}

<受付日59年 4 月 4 日 $>$

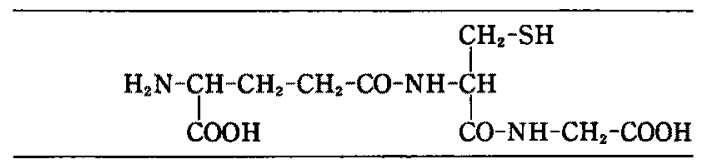

Fig. 1 Chemical structure of glutathion.

59筬，女性，雪科医師。

症例

主訴：肝腫大.

家族歴：特記すべきことなし。

既往歴：领酒歴, 喫煙歴なく, 輸血歴, 肝炎の既往 もない。

現病歴：1982年 5 月, 突然右季助部痛および右側腹

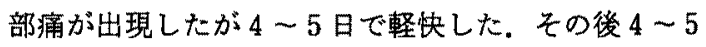
回同様の腹痛発作を反復した，同年 6 月には右䚋腹部 の膨隆に気付き，8月に近医にて肝腫大を指摘された. 同年 9 月20日，精查の目的で当科を受診し，10月 1 日 に入院した。入院までの全経過を通じ，吐血，下血， 発熱の既往はなく，黄疸を指摘されたことはない。

入院時現症：身長 $156 \mathrm{~cm}$ ，体重 $54 \mathrm{~kg}$ ，血田 $120 / 70$

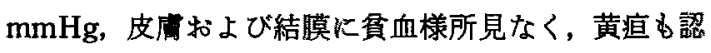
めない，腹部所見では，右上腹部に硬い肝を $9 \mathrm{~cm}$ (右鎖 骨中線）触知するが，辺緣鈍であり，王痛はない，脾 は触知せず，腹水は認めなかった。

入院時検查成緹 (Table 1)：血液検查では白血球数 $15,200 / \mathrm{mm}^{3}$, 赤血球数 $417 \times 10^{4} / \mathrm{mm}^{3}$, 血小板数 $26.9 \times 10^{4} / \mathrm{mm}^{3}$ と白血球増多扰よび軽度の貧血を認 
Table 1 Laboratory data on admission.

\begin{tabular}{ll|ll}
\hline TP & $7.3 \mathrm{~g} / \mathrm{d} l$ & WBC & $15200 / \mathrm{mm}^{3}$ \\
Alb & $3.6 \mathrm{~g} / \mathrm{d} l$ & RBC & $417 \times 10^{4} / \mathrm{mm}^{3}$ \\
GOT & $143 \mathrm{IU} / l$ & Hb & $11.0 \mathrm{~g} / \mathrm{d} l$ \\
GPT & $17 \mathrm{IU} / l$ & Ht & $33.6 \%$ \\
LDH & $708 \mathrm{UU} / l$ & Plat & $26.9 \times 10^{4} / \mathrm{mm}^{3}$ \\
T.Bil. & $1.5 \mathrm{mg} / \mathrm{d} l$ & & \\
D.Bil. & $0.5 \mathrm{mg} / \mathrm{d} l$ & HBsAg & - \\
Al-P & $50.3 \mathrm{IU} / l$ & AFP & $113574.5 \mathrm{ng} / \mathrm{m} l$ \\
$\gamma \cdot \mathrm{GTP}$ & $396 \mathrm{IU} / l$ & CEA & $2.6 \mathrm{ng} / \mathrm{m} l$ \\
TTT & $2.1 \mathrm{U}$ & CRP & $5+$ \\
ZTT & $7.0 \mathrm{U}$ & RA & - \\
Ca & $9.8 \mathrm{mEq} / l$ & ASLO & $<100$ \\
Prothrombin time $89.0 \%$ & ESR & $35 / 1 \mathrm{hr}, 118 / 2 \mathrm{hr}$ \\
\hline
\end{tabular}

めた. 血液生化学検查では総蛋白 $7.3 \mathrm{~g} / \mathrm{d} l$, フルブミン $3.6 \mathrm{~g} / \mathrm{d} l$, GOT $143 \mathrm{IU} / l$, GPT $17 \mathrm{IU} / l$, LDH $708 \mathrm{IU} / l$, $\gamma$-GTP $396 \mathrm{IU} / l$, Al-P $50.3 \mathrm{IU} / l$, 総ビリルビン 1.5 $\mathrm{mg} / \mathrm{d} l$ (直接型 $0.5 \mathrm{mg} / \mathrm{d} l$ ), TTT $2.1 \mathrm{U}$, ZTT $7.0 \mathrm{U}$ と 肝機能異常が認められた。 また CRP (5+), RA (一), ASLO< 100 , プロトロンビン時間 $89.0 \%$ であり, 血沈 は 1 時間值 $35 \mathrm{~mm}, 2$ 時間值 $118 \mathrm{~mm}$ であった。なお， HBs 抗原は陰性, CEA 2.6ng/mlであったが, AFPは $113,574.5 \mathrm{ng} / \mathrm{m} l$ と異常な高値を示した.

入院時特殊検查所見 :

超音波検查 (Fig. 2, a) 一肝両葉に大小不同の echogenic な SOLを多数瑟めた. 腹水詝留はなく, 胆 のう，满缄などには異常がるられなかった。多発性肝 腫湯と䛦断され，超音波検查上では肝細胞癌，転移性 肝癌が最す疑われた。

CT (Fig. 3,a)一一肝のほぼ全葉にわたり直径 $1 〜 5$

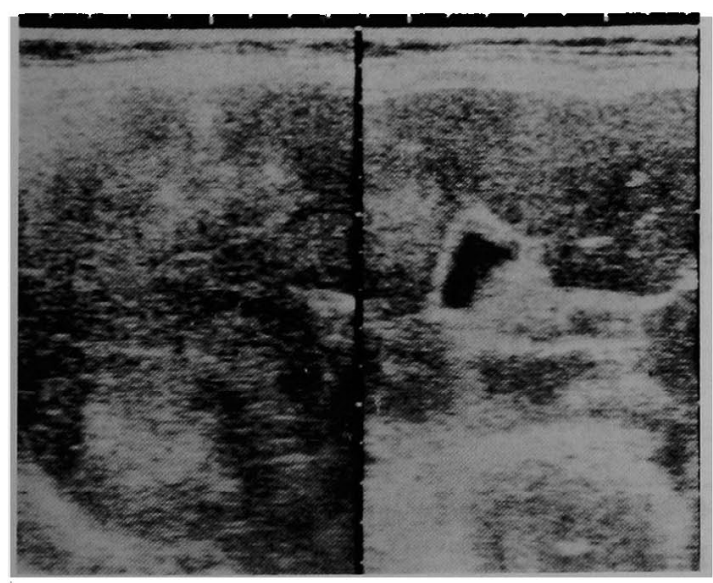

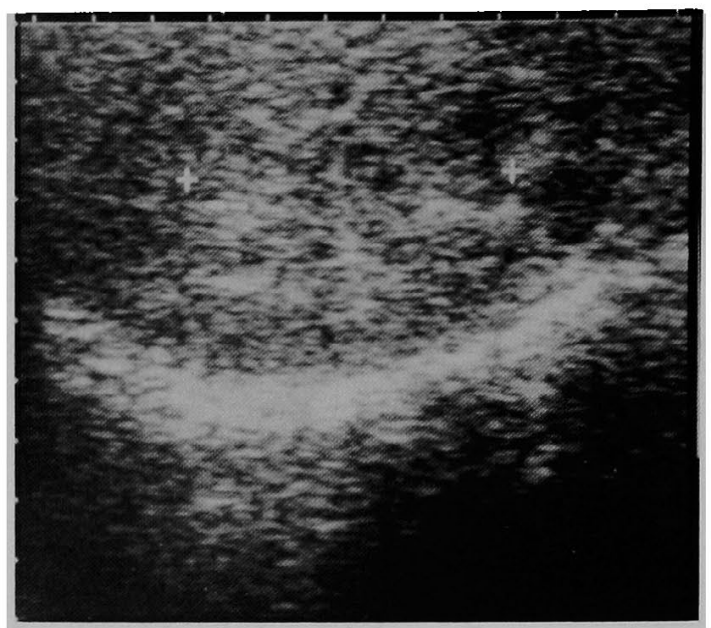

b

Fig. 2 a : Echogram before GSH treatment shows multiple echogenic SOL in the liver. b: Three months after GSH treatment started. This is the only mass in the posterior segment by echogram.

$\mathrm{cm}$ の結節様低漂度陰影を多数認めた，畽煌は体積に して肝全体の $50 \%$ 以上を占め, 造影剂急速静注後も結 節様陰影は濃染像を示さず，比較的 vascularity の低 い病変と考えられた。胆のう，苏，門脈本幹などは正 常であった。診断としては肝細胞癌が疑われるが,vascularity のやや低い点が典型的でなく，転移性肝癌る 否定し得ない結果であった。

腹腔動脈造影 (Fig. 4)一一肝両葉に多発性の結節様 陰影が存在し, 軽度の hypervascularityを認めた。

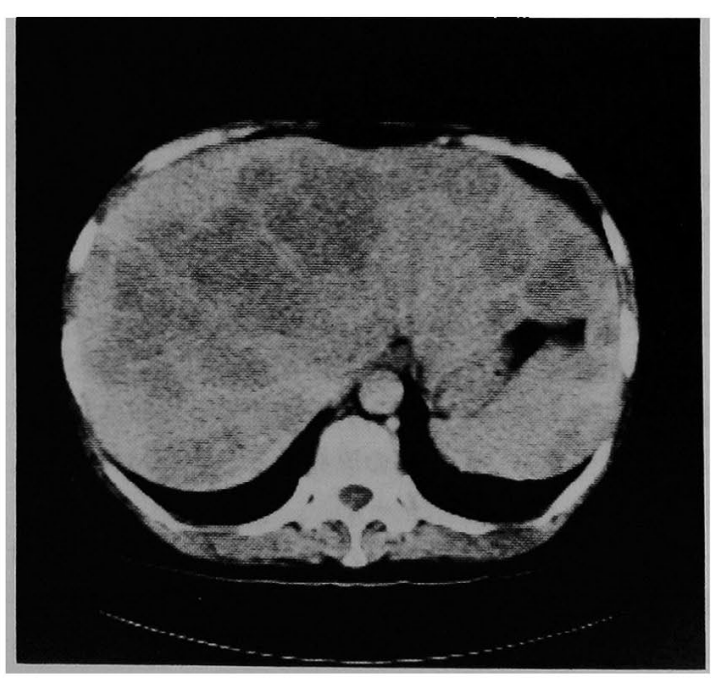

a 


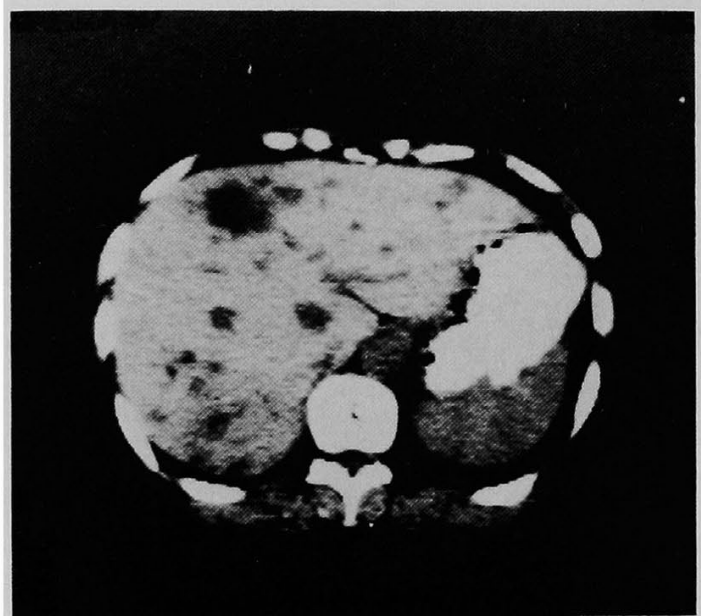

b

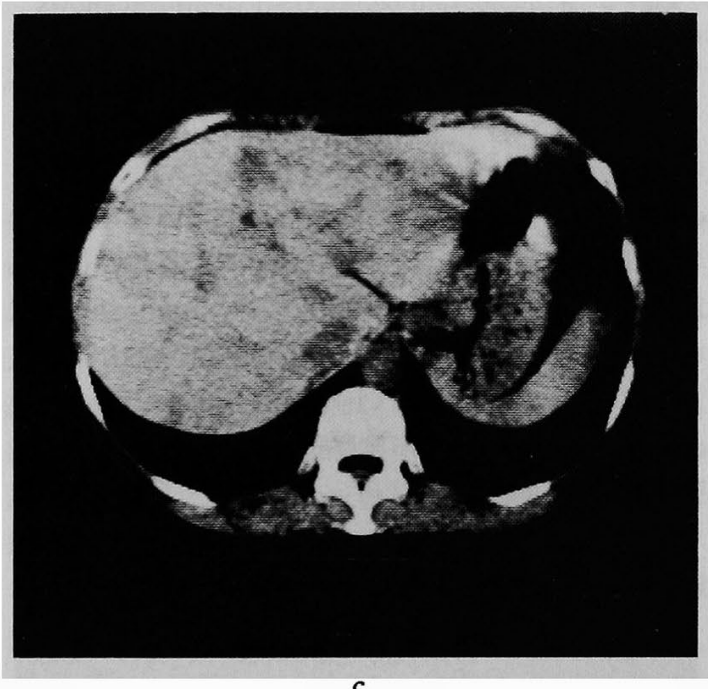

c

肝腫湯吸引細胞診 (Fig. 5) 一一超音波誘導下の腫煌 の吸引細胞診はClass 5であった. 腫瘍は病理学的には 肝細胞癌と考光て矛盾しない所見であった。

その他の検查一一上部消化管レ線検查, 注腸レ線検 査では異常がみられなかった。胃内視鏡検査では胃体 上部の静脈瘤, 十二指腸球部の壁外圧迫所見以外には 異常がなかった．また婦人科的諸検査では卵巣，子宮 とも正常であり，肝腫瑒の原発巣として疑われる所見 はなかった。

入院中経過：以上諸検査の結果よりびまん型の肝細 胞癌と診断され, 局所進展高度のため切除不能と判断 された，1982年10月15日より「GSH 大量療法」を開始 し， $5 \mathrm{~g}$ /日の GSH を連日経口投与した。動脈塞栓療法,

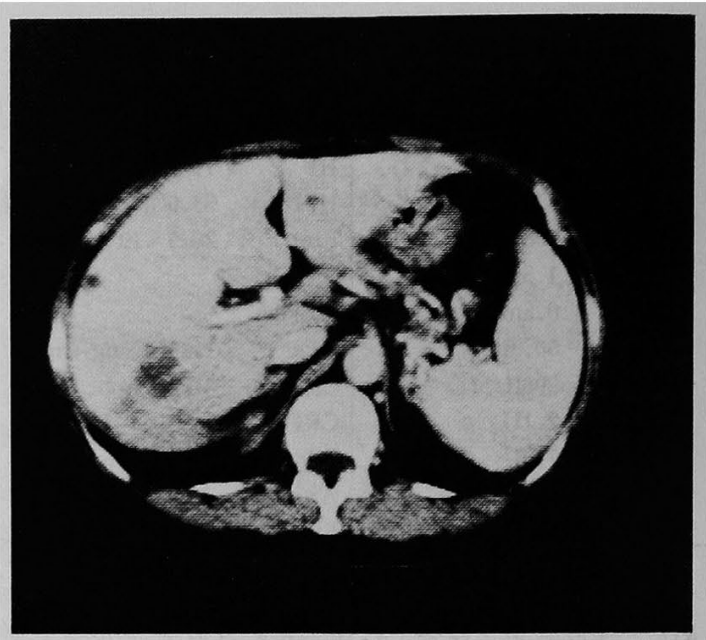

d

Fig. 3 a : CT scan shows multiple SOL extending over bilateral lobes of the liver. (before GSH treatment) $b$ : Three months after GSH treatment started. Multiple cystic degeneration was remarkable. $\mathrm{c}$ : Five months after GSH treatment started. Tumors were reduced and replaced by non-tumor tissue. $d$ : Nine months after GSH treatment started. Reduction was more remarkable with calcification.

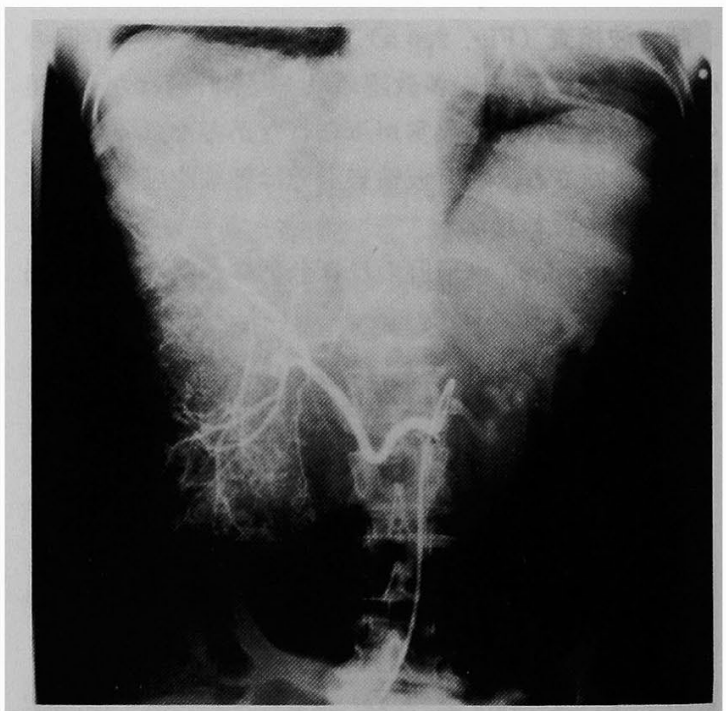

Fig. 4 Angiogram shows hypervascular tumors in the liver.

化学療法, 免疫療法など他の治療は一切これを行わず, 10月23日退院した。

退院後経過：退院後もGSH の投与が唯一の治療と 


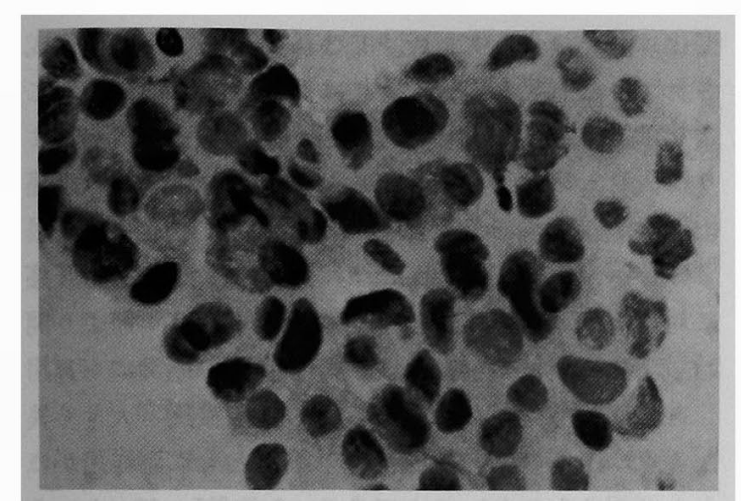

Fig. 5 Tumor cytology shows class 5 . (HE stain, $\times 400$ in original)

して継続された，自覚症状では，入院時にみられた右 上腹部の鈍痛, 重王感拉よび食欲低下, 易疲労感は退 院後むむく消失し, 患者は仕事（歯科医師及び出版 業）に復帰した，その後，自覚的に全く異常なく投与 開始後 1 年 6 力月の現在に至っている。他覚的には, 腹部触診上 $9 \mathrm{~cm}$ (右鎖骨中線) 触知していた肝下縁は GSH 服用開始後急速に縮小し, 約 1 カ月で $2 \mathrm{~cm}$ 触知 するのみとなり，5力月後には深吸気時かすかに触知 するのみとなった。 $10 \mathrm{~g}$ /日投与時に時折, 軽度の下痢 または軟便を認め, 本剂の唯一の副作用と思われたが, 投与を中断する迄には至らなかった。

これら自覚症状, 他覚所見の劇的な軽快と一致して, 諸検査の結果も驚くべき改善を示した，肝細胞癌の量 的指標ともいうべき AFP の経時的変化を Fig. 6に示 す. 入院時 $113,574.5 \mathrm{ng} / \mathrm{m} l$ と異常高值であった AFP は, GSH 投与開始 1 力月後(11月24日)には $890 \mathrm{ng} / \mathrm{m} l$

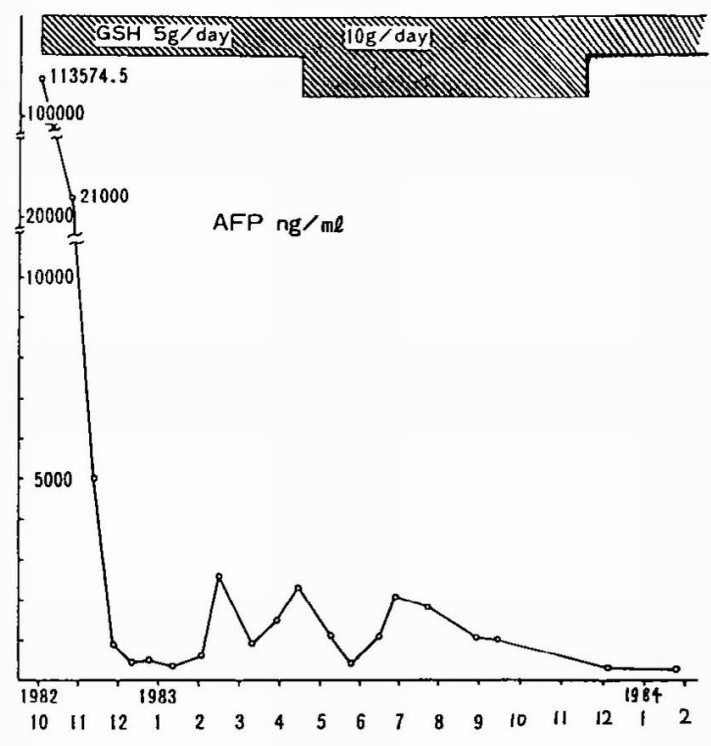

Fig. 6 Changes in AFP.

と著减し， 3 カ月後( 1 月 12 日)には $360 \mathrm{ng} / \mathrm{m} l$ にまで 減少した。 その後 $1,000 \mathrm{ng} / \mathrm{m} l$ 前後で経過したが, 投与 開始 6 カ月後には漸増の傾向を認めたので, 1983年 4 月 9 日より $\mathrm{GSH}$ をそれまでの $5 \mathrm{~g} /$ 日から $10 \mathrm{~g} /$ 日に増 量した．その結果 AFP の堌加は上く抑制され，再度5 g/日の投与量としたにもかかわらず最近では300ng/ $\mathrm{m} l$ 前後の安定した值を維持している. 一般肝機能検 査の経時的推移を Fig. 7亿示す. 各指標により若干の 差はあるが，GSH 投与開始後次第に正常化し現在に 至っている.

これら血清指標のほか，画像診断面より腫呁の質的

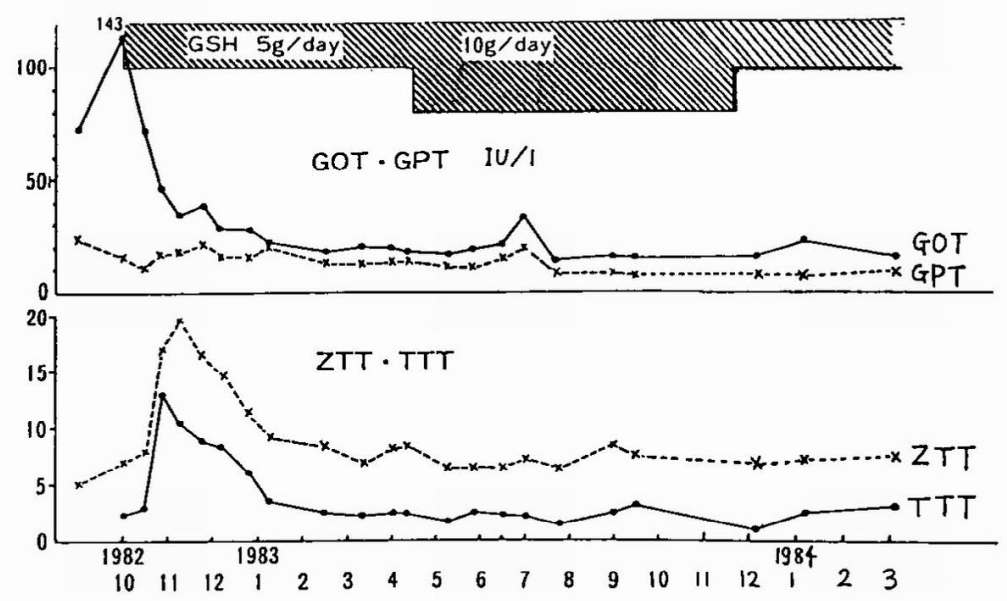

Fig. 7 Changes in GOT, GPT, ZTT and TTT. 
和よび量的変化を把えるべく，CT，超音波検査を定期 的に行ない経過を追った，CTでみると，GSH 投与開 始後腫煌陰影は density の著しい低下を伴いながら綰 小し，3 月月目（1982年12月 7 日，Fig. 3，b）には多 発性の低吸収域に变化している。この变化は, 動脈塞 栓術後などに腫鹪が壊死に陥った時にみられる所見と よく一致している，5力月後(1983年 3 月 2 日, Fig. 3, c)のCTでは，これら多発性の低吸収域はその数と面 積を減し，あたかる壊死に陷った組織が次第に吸収さ れ，非腫鈞肝組織により置換されつつあるかの如き所 見が得られた。 9 カ月後 (1983年 7 月 21 日, Fig. 3,d) のCT では, この低吸収域は更に縮小儿腫場一部辺縟 には石灰化が欢られようになった。 13力月後（1983 年11月16日）飞は残存する低吸收域は肝体積の $5 \%$ 以 下にまで縮小した。

腫場は超音波検査でる CT 上の变化に一致するよう な経過をとった．すなわら，入院時多数みられた大小 不同の echogenic な massは次第にその echogenicity および数，面積を減し，時の経過とともに超音波によ る描出が困難となった。.GSH 投与開始 3 力月目以降は 右葉後区域の mass $(3 \mathrm{~cm} \times 3 \mathrm{~cm})($ Fig. $2, \mathrm{~b})$ 以外描 出不可能となった.

\section{考 案}

GSH は 3 種のアミノ酸よりなるトリペプタイドで， 生体に执いては酸化還元系の賦活, いわ妕る SH 醉素 の賦活，解糖，解毒作用などに重要な役割を果してい る. 薬剤としての GSH は肝疾患, 薬物中毒, アレル ギ疾患などの沿療薬として日常診療の場で広く用い られている。しかし外因性 GSH の吸収, 代謝, 薬理作 用などに関しては末だ不明の点も少なくない。

GSH が実験動物における実験肝癌の治療に有効で

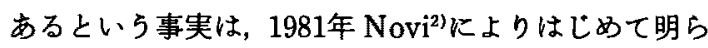
かにされた。彼女は体重100g のラットに Aflatoxin $\mathrm{B}_{1}$ を25 $\mu \mathrm{g}$ /日で週 5 日間, 連続 8 週間経口投与した.この 投与方式を用いれば， 1 年後变でに $100 \%$ のラットに肝 細胞癌が発生することが知られている。彼女はこの肝 細胞癌モデルを用い, Aflatoxin $B_{1}$ の投与終了後16力 月を経過してから， GSH の経口投与を $100 \mathrm{mg} /$ 日で開 始した。これによると，GSH非投与群では Aflatoxin $\mathrm{B}_{1}$ の投与を終了してから20カ月以内に全てのラット が肝畽第により死亡したが，GSH投与群では Aflatoxin $\mathrm{B}_{1}$ 投与終了から24力月の時点て $81 \%$ の ラットが生存中であった。 しかも GSH 投与群ラット の解剖所見は GSH 非投与群と異なり, 肝臓の腫瑒性
変化は全く消失していたといら。これらの事実は完成 された肝細胞癌が GSH 投与により見事に消失したこ とを示している、この研究は癌を化学薬戍の投与に上 り消失せしめた世界で最初の科学的な報告であり, 癌 治療学上特筆すべき発見である。

Novi の報告に注目したわれわれは，切除不能肝癌 に対する「GSH 大量療法」を臨床の場で 2 年前より開 始し切除不能例のみならず，肝切除後の症例にむ適用 し有効例を得つつあるが，既存の癌治療薬と大きく異 なる点は，その強力な癌治療効果とともに副作用が活 とんど認められないことである. 1 日量5～10g とい5 大量投与にもかかわらず，少数例に下利を主とする胃 腸障害がみられたにすぎず，それも投与を中止せざる を得ない注ど重篤なすのは経験していない，切除不能 の末期癌患者は全身状態が衰弱悪化している例が多 く, 副作用の強い治療には耐之得ないことを考慮すれ ば,これは「GSH 大量療法」の優れた特色のひとつで あろち。

われわれは既に200例近い肝細胞癌症例の治療経験 を有するが，その半数以上は町除不能であり，姑息的 治療に頼らざるを得なかったものである。しかし，既 存の如何なる治療法を用いても，切除療法以外で本症 例の如く劇的な経過を示した例や長期生存例は得られ ていない．また文献的に知り得た限りにおいては，薬 剂投与といら非侵䔻的方法に上り本症例の如き末期の 肝細胞癌が消退した例は国の内外に存在しない，本症 例は，実験肝癌といら特殊な条件下でNovi が発見し た GSH の有効性を臨床の場で立証した第 1 例であ $\eta$, 肝癌治療の歴史的転回の岐路に位置する貴重な 1 症例となるであろう.

しかし, 肝細胞癌に対するGSH の作用機序に関す る研究は緒についたばかりであり，現時点では推論の 域を出ない。われわれの経験では経静脈的投与例には 有効例はなかった. 放射性同位元素でラベルした GSH をラットに投与した研究引によれば，経口投与された GSH は大部分がその菓の形で䀒藏にみいだされる。 したがって GSH の代謝産物ではなく，GSH そのむの が有効に作用するのであり，その作用の場は肝蔵であ ろらと推察される。しかし, 肝癌に直接作用するのか, または非癌部肝組織に作用して癌の環境を变化させる ことにより癌を消退せしめるのかなど，作用機序の詳 細に関しては今後の研究成果を待た対ばならない。

$$
\text { まとめ }
$$

本症例は59歳の女性で, AFP, 画像診断, 細胞診な 
どの結果より，肝体積の50\%以上を占める進行したび

型肝細胞癌と診断された。「GSH大量療法」によ

り, 自覚症状, 他覚所見, 検查成績之必劇的飞好転し, 肝癌は体積にして肝全体の $5 \%$ 以下にまで消退した。 臨床の肝細胞癌に GSH が奏効したことを示す内外で 最初の症例である。

\section{文献}

1）日本肝癌研究会：原発性肝癌に関する追跡謂查 一第 5 報一。肝臓 $23: 675-681 ， 1982$
2) Novi AM : Regression of aflatoxin $\mathbf{B}_{1}$-induced hepatocellular carcinomas by reduced glutathion. Science 212 : $541-542,1981$

3) Novi $A M$, Flörke $R$, and Stukenkemper $M$ : Glutathion and aflatoxin- $B_{1}$-induced liver tumors: Requirement for an intact glutathion molecule for regression of malignancy in neoplastic tissue. ANAS $397: 62-71,1982$

\title{
Remarkable regression of hepatocellular carcinoma by reduced glutathion: A case report
}

\author{
Nobuhiro Kawano, Takeshi Nagao, Ryuhei Setoyama and Yasuhiko Morioka*
}

A case of hepatocellular carcinoma (HCC) successfully treated with reduced glutathion (GSH) was reported. A 59 year-old female was admitted to our department due to hepatomegaly. Serum AFP was $11357.5 \mathrm{ng} / \mathrm{ml}$, and angiogram, CT scan and echogram disclosed the presence of HCC (diffuse type) which was subsequently confirmed by liver biopsy. These tumors occupied more than $50 \%$ of the whole liver and surgical intervention was not indicated. Oral GSH therapy, experimentally suggested effective for HCC by Novi, was applied to this patient and she has been followed up for 18 months at the outpatient clinic by liver function test, serum AFP, echogram and CT. Three months after the beginning of GSH administration, remarkable decrease of AFP was observed with general improvement and disappearance of tumors in the liver on CT and echogram. Eighteen months after GSH treatment started, the tumors have regressed to below $5 \%$ of the whole liver on CT and this patient has fulfilled perfect social rehabilitation. This is the first clinical report of successful treatment of $\mathrm{HCC}$ by GSH, and the mechanism of GSH to $\mathrm{HCC}$ was also discussed.

\footnotetext{
* First Surgical Department, University of Tokyo (Tokyo)
} 